\title{
Izrazi za sneg in smuči v slovenski smučarski terminologiji
}

\author{
LJUDMILA BOKAL \\ Inštitut za slovenski jezik Frana Ramovša ZRC SAZU, Novi trg 2, SI - 1000 Ljubljana, \\ ljudmila.bokal@zrc-sazu.si
}

SCN III/1 [2010], 109-143

\begin{abstract}
Sneg in smuči sta temeljna termina smučarske terminologije. Pomemben delež izrazov iz obeh pojmovnih skupin je v preteklosti živel v narečjih. Od tu so prešli v knjižni jezik in so sedaj nepogrešljive enote slovenske smučarske terminologije. Živost le-te se izkazuje tudi v izraznem odzivanju na nove tehnološke dosežke (smuči karving).

Snow and skis are the fundamental terms of skiing terminology. In the past a significant share of the terms in both concept groups thrived in dialects. From there they passed into the standard language, where they are now indispensable units of Slovenian skiing terminology. The vitality of this terminology is also evident in its responsiveness to new technological achievements (carving skis).
\end{abstract}

Ključne besede: sneg, smuči, smučanje, smučarska terminologija, smučarsko izrazje

Key words: snow, ski, skiing, ski terminology

Številnost izrazov za predmetnost določenega področja je premosorazmerna s pogostostjo pojavljanja pojma $\mathrm{v}$ stvarnosti. Čim bolj je neki pojav zasidran $\mathrm{v}$ stvarnosti, tem več izrazov zanj obstaja. To leksikološko pravilo je strokovna opora pričujočemu sestavku. Predpostavljamo, da ga je mogoče povezati s splošnimi dejstvi iz razvoja smučarstva na Slovenskem.

Odločitev za podrobno obdelavo dveh izrazov iz določene terminologije izhaja iz strukturnih značilnosti delnih leksikalnih sistemov. Izrazni sistem vsake stroke namreč sestavljajo izrazi, ki so polno umeščeni v njen pojmovni sistem, so zanjo temeljni, bistveni, in tisti, ki v stroki gostujejo, so delno umeščeni in prispevajo $\mathrm{k}$ njeni interdisciplinarnosti. Na temeljnih pojmih se gradi določena terminologija. Za smučarsko terminologijo sta sneg in smuči temeljna, relevantna pojma. 
Razprava se navezuje tudi na predpostavko o različnosti socialnozvrstne jezikovne podlage določene terminologije. Stroke namreč niso enovite, kar zadeva socialnozvrstni izvor njihovih temeljnih pojmov. Za novejše terminologije, na primer za računalniško, elektrotehniško, ekonomsko je značilno, da je njihova socialnozvrstna podlaga knjižni jezik. Pomembno vlogo pri tem odigra časovni vidik. Pri terminologijah, ki so stare, katerih temeljni pojmi in njihova jezikovna uresničitev so se pojavljali v času, ko knjižni jezik še ni bil funkcijsko razvejan in formiran na taki stopnji, kot je danes, pa obstaja možnost, da je njihova socialnozvrstna podlaga narečje. Izrazi, ki so se najprej pojavljali v narečju, so sčasoma prehajali v novo socialno zvrst, v knjižni jezik. Predpostavljamo, da to velja za smučarsko terminologijo. S tega stališča bi bilo mogoče raziskati še geografsko, planinsko, čebelarsko terminologijo. Narečno izrazje tako dobiva novo, tvornejšo vlogo.

Splošno znano je, da se je smučanje razvilo v skandinavskih deželah, od koder se je razširilo v Srednjo in Južno Evropo. Članek Arnolda Dalena Skandinavska smučarska terminologija (1998) obravnava razvoj smučarstva prav s stališča socialnozvrstnih jezikovnih dejstev. Dalen raziskuje razširjenost določenih smučarskih izrazov na skandinavskem območju in pri tem izhaja prav iz narečja. Trdi celo, da bo »med veliko raznovrstnostjo terminov, ki jih je našel v skandinavskih narečjih /razbral/ tiste, ki lahko osvetlijo zgodovino smuči«. (Dalen 1998: 53) Nato osvetljuje mednarodni izraz za smučarsko zvrst slalom: »Izvorno je bila ta besedotvorna zloženka, ${ }^{1}$ ki pomeni 'poševna sled navzdol', razširjena le na vzhodni in jugozahodni Norveški in je pravzaprav naključje, da je postala internacionalni termin.« V nadaljevanju opisuje širjenje izraza sredi 19. stoletja zaradi zmage smučarjev v Kristijaniji na Norveškem, ki so gojili to zvrst smučanja, in ugotavlja, da je bil izraz slalom najprej »lokalni termin«. (53) To lahko razumemo kot narečno besedo oziroma s stališča terminologije kot narečni termin.

Izhajajoč iz širšega konteksta, navedena razprava prehaja na slovensko območje. Namen sestavka je raziskati temeljna termina slovenskega smučarskega izrazja, tudi s socialnozvrstnega stališča. Smiselno zapovrstje obdelave izrazov sneg in smuči daje prednost izrazom za sneg.

\section{Izrazi za sneg}

Etimologija izraza sneg seže preko starocerkvenoslovanščine, praslovanščine do indoevropščine. (Snoj 1997: 588) »Prvotni pomen je verjetno *'kar je obležalo, kar se je prilepilo (na rastline, na tla)'«, kar je mogoče sklepati iz sorodnih besed v stari indijščini. Fonemi izraza se niso veliko spreminjali, saj Snoj med drugim navaja staroindijsko besedo snihyati v pomenu 'lepi se, je masten, vlažen', asnihat v pomenu 'je obležal' in snéha 'lepljivost, lepljiva snov, sluz,

\footnotetext{
${ }^{1}$ Norveško: sla > strmo pobočje, laam > sled smuči v snegu (Aleš Guček ustno).
} 
slina' idr. (588). Po Bezlaju (Bezlaj 1995: 279) se je izraz sneg v slovenskih slovarjih pojavil že v 16. stoletju. Zapisal ga je Megiser, v 18. stoletju pa Pohlin. Beseda je bila torej nepogrešljiva enota leksikalnega sistema že ob začetkih slovenskega knjižnega jezika, sicer ne bi bila zajeta v prvih slovarjih, v katerih je zapisana slovenščina. Da je izraz vzorčen za raziskavo slovenščine, še posebej njegove fonemske različice $\mathrm{v}$ slovenskih narečjih, dokazuje tudi upoštevanje v vprašalnicah za Slovenski lingvistični atlas in sestavke, izvirajoče iz njih. (Benedik 1990: 213)

Maks Pleteršnik ima v svojem Nemško-slovenskem slovarju iz leta 1894/95, ki velja za najbolj popoln popis izrazja slovenskega jezika ob koncu 19. stoletja, v katerem so dokumentirani tudi viri za izraze, iz besedne družine sneg naslednje izraze: snég, snégast, snegúlja, snežák, snéžec, snéžek, snéžen, snežén, snežénka, snéžič, snežina, snežinka, snežišče, snežiti, snéžnat, snežníca, snežník, snežnína, snežnják, snežnobél, vsega 20 izrazov. Slovar slovenskega knjižnega jezika (SSKJ) pa zajema: snég, snegobrán, snegolòm, snegolòv, snegolôvec, snegomér, snegôvje, snežák, snéžec, snéžek, snéžen, snežén, snežênje, snežénka, snežina, snežinka, snežišče, snežiti, snéžka, snéžnat, snežníca, snežník, snežniški, snežnják, vsega 25 izrazov. Porast je opazen v pojmovni skupini priprav (snegobran, snegolov, snegolovec, snegomer; snežka). V slovarskem sestavku Pleteršnik navaja vrste snega: južen sneg, suh sneg, droben sneg, zeleni sneg. Poleg njih navaja kot iztočnice še izraze babje pšeno, celec, inje, ivje, (snežni) poprh, tudi prha, sren, srenec, srež, vejavica. Ob njih mu je bilo poleg avtorskih besednih zbirk (pri celcu Cafa, Murka, pri izrazu inje Cigaleta (Terminologijo) in Erjavčevo Mineralogijo, pri izrazu poprh Vodnika preko Cigaleta in pri izrazu sren Cafa, Miklošiča, Murka, Cigaleta, Janežiča) smiselno dodati tudi širše pokrajinske oznake: ob izrazu celec vzhodno Štajersko, ob inje jugovzhodno Štajersko in Slovenske gorice, ob izraz poprh Gorenjsko in ob izrazu sren Dolenjsko in Gorenjsko. Navajanje širših geografskih območij je znamenje razširjenosti izrazov v narečjih.

Ob izrazih iz Pleteršnikovega slovarja je smiselno obdelati njegovo navajanje virov oziroma citatov in odločanje za posameznega od njih. Pleteršnik v uvodu v svoj slovar omenja široko socialno podlago svojega slovarja. Pošiljali so mu besede $\mathrm{z}$ različnih slovenskih področij; pravi, da je tudi sam nabiral besede »po ustnem občevanju«. Geografsko razsežnost še posebej poudari ob slovarski zbirki Oroslava Cafa:

Njegova nabirka je zelo obsežna. /.../ Bogatijo jo /.../ zbirke besed med narodom po vseh slovenskih krajih nabranih /.../, zlasti pa od rezijanskih, ogrskih in vzhodnoštajerskih Slovencev slišanih /.../

Miklošičev delež je Murkova zbirka, pomnožena z besedami, »med narodom nabranih«.

Široka socialna podlaga je Pleteršnika prisilila k odločitvam o selekciji besed v slovar in v naslednji stopnji k ustreznemu prikazu. Pri izbiri med citiranjem in pokrajinsko navedbo vira se je odločil za navajanje virov: 
Npr. ako so viri kazali, da je kaka beseda med narodom znana in tudi v starejši literaturi rabljena, $v$ novejši pa ne ali ne tako pogostoma ali če je sicer beseda med narodom znana, v knjigi pa redko rabljena, v takih in enakih slučajih so se rajši pripisovali viri.

Navedeno Pleteršnikovo trditev bomo navezali tudi na vire za izraz smuči. Delo Rudolfa Badjure (1881-1963), ki s stališča terminologije, ${ }^{2}$ tudi narečne, ${ }^{3}$ še čaka na obdelavo, je v okvirih tukajšnje obravnave pomembno posebej zaradi njegovega prizadevanja za uveljavitev novega športa - smučanja. Sadovi tega niso samo smučarski tečaji, ki jih je sam organiziral in vodil, ampak tudi dve deli ${ }^{4}$ s področja smučarske terminologije, popis smučarskega izrazja z naslovom Smuška terminologija $(1921)^{5}$ in strokovna knjiga o smučarstvu z naslovom Smučar (1924). Smuška terminologija ni s stališča predmeta tukajšnje obravnave pomembna samo zaradi vsebujočih terminov o snegu in smučeh, ampak tudi zaradi metode pridobivanja izrazov. Njegov popis smučarskega izrazja namreč ne temelji samo na danes priznani metodi o izhajanju iz gradiva in rabe besed, ki je odločilna za njihovo registracijo v zbirkah, pač pa je vire tudi dokumentiral. Geografska območja, ki so kot vir izrazov navedena v kratkem uvodu v Smuško terminologijo, so: Bl - Bloke, Bo - Bohinj, Pl - Planina Sv. Križ nad Jesenicami, M - Mojstrana, K - Križka planina, poleg Blok torej Gorenjska. Pri Badjuri so torej konkretno omenjena narečna območja, od koder so zapisani izrazi. Prizadeval se je torej za uveljavljanje živega jezika. Kot navaja Borut Batagelj v svoji disertaciji Socialna zgodovina smučarstva na Slovenskem so v njegovi osebni zapuščini ohranjene beležnice, ki razodevajo prizadevno raziskovalno delo na terenu. ${ }^{6}$ Uvod v Smuško terminologijo je pravi apel k rabi domačega izrazja in zbiranja tega na terenu:

Držimo se pristne, domače, narodove govorice in kdor čuje in nabere kaj novega, naj objavi v 'Sportu', da čimpreje in še bolje izpopolnimo svoje besedišče.

$\mathrm{V}$ razdelku z naslovom Snegovi je najprej naveden najširši izraz sneg z dopolnilom, da je »suh ali moker, mehak ali trd«. V nadaljevanju so omenjeni posamezni izrazi, razlage zanje in krajšava za področje, na katerem se izraz rabi:

${ }^{2}$ Badjurov popis smučarskega izrazja je ena prvih terminoloških obravnav določenega strokovnega področja pri nas.

${ }^{3}$ Tu gre omeniti še njegovo Ljudsko geografijo, 1953.

${ }^{4}$ Badjura je leta 1956 izdal še tretje delo s področja smučarstva z naslovom Bloško starosvetno smučanje in besedje. Glede na obravnavano temo, ki skuša slediti razvoju smučarstva, bosta v tem sestavku obravnavani le dve, Smuška terminologija in Smučar.

${ }^{5}$ Druga izdaja v samozaložbi leta 1931.

${ }^{6} \gg$ V neko gostilno v Metuljah je zvabil sedem tamkajšnjih očancev, 'ki so že na drugi svet škilili'. Zanimalo ga je vse, kar so mu sogovorniki povedali. Beležil je tako, da je težko dohajal s svinčnikom na papirju. Posebej ga je pritegnila smučarska terminologija, iz katere nabora izrazov je črpal tudi številne izraze, ki so kasneje odločilno zaznamovali moderno slovensko smučarsko terminologijo.« (Batagelj 2008: 36)

${ }^{7}$ Badjura je leta 1920 v nekaj številkah v tedniku Sport objavljal slovensko smučarsko terminologijo, ki jo je leta 1921 izdal v samostojni knjižici. 
pršič /.../ t. j. sipek, suh, puhel sneg, kakor da bi ga presejal na rešetu (Bo); prášnik I.../ sneg, ki praši, npr. ta smučar pa tako leti, da kar praši (Bl in Pl); prh /.../ ali poprh, npr.: po srenu je pal droben prh (poprh); če nov sneg 'poprhne' po srenu, takrat je najboljša 'smuka' /.../

Badjurovo razpravljanje o izrazih za sneg s terenskimi podatki o rabi besede izhaja iz narečne podlage. Za krepko pisano iztočnico so navedene slovnične lastnosti: rodilnik in oznaka za spol, ki ji sledi razlaga pojma. Njegov natančni jezikovni čut se odraža tudi v tem, da je izraze naglasil. Razlage izrazov so natančne in zajamejo bistvo posameznega pojma, ki izvira iz izkušenj. Podpira jih praktičen namen priporočiti »kdaj je smuka ugodna, kdaj neugodna ${ }^{8}{ }^{8}$

Badjura je vrste snega opisoval tudi v delu Smučar (1924). V razdelku Sneg razkriva njegovo veliko kvalitativno pestrost: »Med snegom in snegom je velik razloček. 100 sort ga je!« (Poudaril Rudolf Badjura.) (Badjura 1924: 31) Našteva izraze pršič, prášnik, sréž, ivje, pŕh ali popŕh, srén, júžen, ojúžen, odjúžen snég, móker, otájan sneg, uležán, kompákten, stár sneg, súhi (določna oblika!), osrenica ali osrénjen, osreničast, skórjast, požléd, zastrúgi, obléčen snég, cél snég. Podatkov o terenski rabi besed nima več, a etimološki podatek, da so zastrugi ruski izraz še razkrivajo njegove prizadevne jezikovne silnice.

Od strokovnih popisov izraza sneg preidimo k navedbam v jezikovnih priročnikih. Ta izraz je po nekem čudnem, prejkone človeškem dejavniku prvič zajet v slovenskih pravopisih šele leta 1950. Da ga ni zajel Levčev Slovenski pravopis iz leta 1899, bi bilo zaradi neobsežnosti njegovega slovarskega dela še nekako razumljivo, da pa je izpadel iz Breznikovega iz leta 1920 in BreznikRamovševega iz leta 1935 pa je najbrž pomota. ${ }^{9}$

Ob popisu izrazov za sneg in vse, kar zajema snegoslovje ali nivologija, ne gre prezreti dela Pavle Šegule Sneg, led, plazovi (1986). V njem se pojavijo besedne zveze, ki do sedaj še niso registrirane: ívnat snég, lúskast snég, napíhan snég, ráhel snég, zaívjen snég, ob mŕzlem v registru celo tópel snég. Avtor ob preobrazbi snega uvede celo nove besede: zŕnjenje (Šegula 1986: 39), sréženje (43), srénjenje (46). Omemba nóvosti izrazov je hkrati z avtorjem zabeležena $\mathrm{v}$ opombi pod črto. Izraz srenjenje je uvedel C. Malovrh, sreženje in zrnjenje pa Pavle Šegula.

Terminološki slovar Sneg in plazovi avtorja Pavla Šegule (1995) prav tako prinaša množico novih terminoloških zvez: nakódrani snég, púhasti snég, vé-

${ }^{8} \mathrm{Z}$ enakimi nameni se kopičijo termini s področja terminologije o snegu tudi danes. Primerjaj nasvete iz knjige o turnem smučanju z naslovom Skrivnosti nedotaknjenih strmin: »Mraz je, sneg je suh in nepredelan. V tanki snežni odeji se ob hudem mrazu pospešeno razvija globinski srež. Pršič in plazovi nas čakajo več dni. /.../ Na prisojnih pobočjih nas vse bolj razveseljuje sren, na osojah in v gozdu pa najdemo vse, od pršiča do lomljivih klož.« (Črnivec, Terčelj 1997: 47) (Termine poudarila L. B.)

${ }^{9}$ To še toliko bolj, če upoštevamo obstoj fraz »to me toliko skrbi kakor za lanski sneg« in »za to toliko maram kakor za lanski sneg«, kar pomeni 'nič'. Beseda je namreč po zapletenih zakonih psiholingvistike pristala kot jezikovna okamenina na doživljajskem področju človeške indiferentnosti. 
zani snég, žívi snég, sípki snég, spomladánski snég, ki so bolj ali manj živele v knjižnem jeziku, le da so se zdaj našle druga ob drugi.

$\mathrm{Ob}$ teh izrazih gre omeniti tudi rabo določne oziroma nedoločne oblike ob posameznih zvezah. Vprašanje določne in nedoločne oblike je pri teh zvezah vedno aktualno in deloma nepredvidljivo. Pri tem se ni moč izogniti občutku, da je določna oblika nekako prisiljena. Medtem ko je pri nekaterih zvezah, npr. umétni snég, plôvni snég vrstnost izraza nedvoumna, pa je pri drugih zvezah (móker, súh, stár, nòv snég) gotovo v ospredju pomenska sestavina lastnosti, kvalitete in ne vrstnosti, kar pogojuje rabo v nedoločni obliki. Lahko bi rekli, da so te besedne zveze dvooblikovne; ${ }^{10}$ če je v ospredju »globinsko« gledanje enega tipa snega, določitev kvalitete, je besedna zveza v nedoločni obliki (na primer suh sneg, moker sneg, star sneg), če pa gre za določitev tipov v horizontalni smeri, pa je določna. Nekatere zveze bolj težijo k prvemu, druge k drugemu opredeljevanju.

Obsežno zbirko besednih zvez z jedrnim samostalnikom sneg zajema tudi gradivo za Slovenski smučarski slovar, ki v sodelovanju s Smučarsko zvezo Slovenije nastaja v Sekciji za terminološke slovarje Inštituta za slovenski jezik Frana Ramovša ZRC SAZU. Različni vidiki oziroma pomenske sestavine, ki napajajo besedne zveze s sneg, so:

- glede na izvor: izpíhani snég, kompáktni snég, narávni snég, téhnični snég, umétni snég, ${ }^{11}$

- glede na izoblikovanost v naravi: jámičasti snég, kónčasti snég, skórjasti snég,

- glede na obdelanost z vetrom: klóžasti (klóžnasti) snég, klóža, mêhka klóža, napihani snég, živi snég, vêjavica,

- glede na prehojenost: célec, céli snég,

- glede na obdelanost na smučišču: gládki snég, poteptáni snég, teptáni snég, zbíti snég,

- glede na obliko kristalov: búnčičasti snég, drobnozŕnati snég, mókasti snég, prhki snég, popŕh, srhlína (SSKJ), sípki snég, grobozrnati snég, zŕnati snég, zŕnec, sréž, globínski sréž, površínski sréž, bábje pšêno,

- glede na skorjasto izoblikovanost vrhnje plasti snežne odeje: osrénjeni snég, osrnicasti snég, srén,

- glede na gibanje plasti v snežni odeji: drséči snég, plôvni snég, plávni snég, kotaléči se snég, polzéči snég,

${ }^{10}$ Ta trditev v normativni slovnici najbrž ne bi bila potrjena, a jo raba registrira tudi pri besednih zvezah z drugih področij, npr. bel kruh, črn kruh.

${ }^{11}$ Umetni sneg je bil prvotno izraz za sneg, izdelan s posebnimi napravami (prvič leta 1950 brata Tropeano v ZDA in na smučišču prav ta dva leto dni kasneje), vendar so kasneje z dogovorom na strokovnem srečanju izraz umetni sneg zamenjali z izrazom kompaktni sneg. Umetni sneg ni izdelan iz umetnih primesi, kemikalij, temveč je narejen s pripravami, ki imajo posebne šobe, z mešanico vode in zraka pod visokim ali nizkim tlakom. Izraz umetni sneg bi namreč lahko kdo razumel, da je skrajno škodljiv okolju in naravi (pojasnilo Aleša Gučka). 
- glede na stopnjo sprijetosti v snežni odeji: kompáktni snég, sprijéti snég, nèsprijéti snég, uležáni snég, pútr,

- glede na debelino snežne odeje: debéli snég, globôki snég,

- glede na vsebnost vode: gníli snég ali gnílec, gnój, mókri snég, omečêni snég, otájani snég, púhli snég, môkri srénec, súhi snég,

- glede na precejšnjo stopnjo vlage: lépki snég, vlážni snég,

- glede na optimalno stopnjo vlage: pršič, srénec, súhi srénec,

- glede na temperaturo, pri kateri naletava: júžni snég, mêhki snég,

- glede na težo: láhek snég, púhasti snég, púhec, ráhli snég,

- glede na stopnjo zmrznjenosti: ledéni snég, zmŕznjeni snég, tŕdi srénec,

- glede na spremembo zaradi toplote: odjúženi snég, ojúženi snég, oméčni snég,

- glede na časovno bližino pojavitve: nòvi snég, svéžec,

- glede na časovno odmaknjenost pojavitve: stári snég,

- glede na postopno »minevanje«: kopnéči snég,

- glede na dolgotrajen obstoj: véčni snég, zelêni snég, firn,

- glede na psihično ugodno počutje: vesélec,

- glede na površino snežne odeje: obléčeni snég,

- dialektizem: kukavičji sneg - 'zadnji sneg v letu, ki pade, ko že poje kukavica'. ${ }^{12}$

Ob množici pridevniških zvez z jedrnim samostalnikom sneg jih je tudi nekaj, ki besedotvorno niso vezane na ta koren. Večina je stilno nezaznamovanih; s področja turnega smučanja pa so strokovno pogovorne (putr). To je namreč področje smučanja, ki je po prostoru »gibanja« primarno in s stališča vrst snega najbolj aktualno. Ker se spreminjajo okoliščine drsenja, je poimenovalna potreba tu še aktualna, zato nastajajo novi izrazi (putr, gnoj, svežec, veselec). Sicer so to obrobni izrazi, mogoče v rabi samo v ožjih krogih in jih knjižni jezik in uradna smučarska terminologija sprejema kot obrobne, pa vendarle kažejo na rodovitnost slovenskega jezika. Smučanje je do pojava športnega smučanja med obema vojnama bilo pravzaprav samo turno smučanje, le športni vidik je bil bolj ali manj prikrit.

\section{Izrazi za smuči}

Splošno znano je, da se je na Slovenskem smučarstvo najprej razvilo na Blokah. Prvi znani zapis o smučanju na Slovenskem v Valvasorjevi Slavi vojvodine Kranjske iz leta 1689 se nanaša prav na bloško smučanje. ${ }^{13}$ Natančen opis

12 Besedna zveza kukavičji sneg je poznana v Žireh.

${ }^{13}$ Valvasorjev zapis o smučanju na Blokah je tak: »Poleg tega poznajo kmetje ponekod na Kranjskem, zlasti na Turjaku in tam okoli, neki redek izum, kakršnega nisem videl še nikoli v nobeni deželi, namreč da se spuščajo pozimi, ko leži sneg, po visokem hribovju $\mathrm{z}$ neverjetno naglico $\mathrm{v}$ dolino. $\mathrm{V}$ ta namen vzamejo po dve leseni deščici, četrt palca debeli, pol čevlja široki in približno pol čevlja dolgi. Spredaj sta deščici ukrivljeni in 
drsenja po snegu z napravo, kateremu so podlaga $\mathrm{v}$ prevodu opisno imenovane »lesene deščice«, sproža domnevo, da so morali za to napravo obstajati posebni izrazi. Trditev izhaja iz najbolj vsakdanjega preprostega jezikovnega načela, da ima predmet, ki obstaja v stvarnosti, še posebej, če je to povezano $\mathrm{z}$ določeno vsakdanjo uporabnostno funkcijo, ime. Kot posebna oblika gibanja je glede na običajna pravila o poimenovanjih določenega pojmovnega polja po vsej verjetnosti obstajal tudi izraz za tako gibanje. ${ }^{14}$ Kateri so bili ti izrazi, je za sedaj žal neugotovljivo. Predvidevamo pa lahko, da so vsebovali pomensko sestavino drsenja, kar posredno potrjuje tudi etimologija izraza smuči. Ta se navezuje na besedno družino smučati. Izraz smučati seže v cerkvenoslovanščino in je pomenil 'drseti, plaziti se'. Izraz je rekonstruiran tudi v praslovanščini s pomenom '(hitro) drseti, hitro se premikati'. (Bezlaj 1995: 277; Snoj 1997: 587) Predvidevamo, da je bila ta pomenska sestavina prvotna podlaga tudi teh izrazov.

Boris Orel navaja, da je prvi do sedaj znani zapis za to napravo v slovenščini izraz šmeče. Uporabil ga je Jožef Bevk, kaplan na Blokah, ki je pod psevdonimom Podgrivarski v Kmetijskih in rokodelskih novicah leta 1845 v sestavku z naslovom Huda zima na Blokah in raba šmečev natančno opisal, kakšne so tedanje smuči bile..$^{15}$ (Orel 1964: 46) Orel omenja še Frana Erjavca. V sestavku

navzgor zavihnjeni, na sredi je usnjat jermen, da se vtikajo noge vanj; na vsako nogo se pritrjuje po ena taka deščica. $\mathrm{K}$ temu ima kmet še čvrsto gorjačo $\mathrm{v}$ rokah; to si nastavi pod pazduho pa se drži ob nji močno nazaj, da mu je za oporo in krmilo, in tako se driča, lahko bi napisal tudi smuka ali leti po najbolj strmem pobočju. Zakaj vtem, ko stoji na deščicah in se prav trdno, da, z vso močjo naslanja na gorjačo, jo reže tako urno navzdol, da presega skoraj vsako domišljijo in v hitrosti nič ne zaostaja za tistimi, ki se na Holandskem z drsalkami vozijo po ledu. Vsak trenutek se utegne izogniti vsemu, kar mu je napoti, bodi že drevo ali skala, bodi kaj drugega takega. Noben hrib mu ni prestrm, noben z drevjem tako gosto porasel, da se ne bi mogel na ta način drkati po njem. Zakaj kjerkoli mu stoji kaka ovira napoti, povsod je kos svoj smuk po kačje kljukati in vijugati. Če pa je pot povsem prosta, nezarasla in brez opotike, se drevi lepo naravnost, in sicer venomer tako stoje in navzad oprt na gorjačo: te se drži možak s tolikšno silo in močjo, tako čvrsto in trdo, ko da bi ne imel nobenega uda in nobenega sklepa.« Valvasor 1994: 94.

${ }^{14}$ Običajne besedotvorne pomenske kategorije, ki se pojavijo ob določenem pojmu, so pri samostalniku: 1. vršilec dejanja (oseba), 2. vršilnik dejanja (predmet, stvar) 3. dejanje, stanje, potek 4. rezultat dejanja 5. mesto, čas dejanja 6. snov. Prim. Jože Toporišič, Slovenska slovnica 2000, str. 161-169.

15 »Hočem pri ti priliki tudi popisati eno prav pripravno in priročno orodje, kteriga se pozimi tukej ljudje poslužvajo in ktero je tudi priporočevati tistim, kteri v merzlih krajih, kjer jih debel sneg in zametje nadlegujejo, stanovati morajo. To orodje imenujejo šmeče in tudi plohi se mu pravi. Šmeče so bukove deske, po 5 čevljev dolge, 6 do 7 palcev široke in pol palca debele. V sredi so z usnjato podvezo previdene, kamor se stopalo vtakne, de k nogi desko drži in kjer se stopi, de ne polzi, je klobučina perbita. Sprednji konec šmečev je senem enak; de v sneg ne rije, je nekoliko zakrivljen, kar se lahko naredi, če se $\mathrm{v}$ to rabo odločena in gladko razoblana deska pri ognju ogreje in umetno zakrivi /.../« 
Iz potne torbe, objavljenem v Letopisu Matice slovenske leta 1883, pravi, da sicer rabijo izraz smuči v pomenu sani, le »okrog Loža, Oblok in Lašč imenujejo smuči, f. pl., ${ }^{16}$ nekako naredbo za hojo po snegu, ki je različna od 'krpelj'. ${ }^{17}$ Nadalje je izraz zapisan v pesmici Frana Levstika Kako je v Korotani (Šala). (Batagelj 2008: 29) Batagelj navaja še druge izraze za smuči, ki so se pojavljali v časopisju in revijah ob koncu 19. stoletja: snéžke na Trnovski planoti, leséne drkalice, leséne cókle, plôhi (izraz je zapisal Podgrivarski kot sopomenka za šmeče), skíje, dôlge kŕplje na Pohorju (Batagelj 2008: 53, 134, 152).

Maks Pleteršnik v svojem Nemško-slovenskem slovarju iz leta 1894/95 besedno družino smuč prikaže z naslednjimi izrazi: smúč, smúčati, smúče, smučice, smúčkati, smúčke, smúka. Za izraz smuč, ki je koren v besedni družini, so navedeni trije pomeni. Prvi ima nemški ustreznik die Schlittenkufe, slovensko sanica, z viri Oroslav Caf (C.) in Marko Pohlin (Poh.). Pleteršnik je opazil pogosto rabo v množini, zato je navedel množinsko obliko »smuči« z nemško ustreznico der Schlitten, slovensko sani, sanke. Vir za ta pomen je Matej Cigale in z območja Krasa Fran Erjavec (Iz popotne torbe). Drugi pomen je za našo razpravo najbolj zanimiv. Nemške ustreznice Pleteršnik ni našel, zato je dodal opis: eine Art Schneeschuhe, v dobesednem prevodu »vrsta čevljev za v sneg«. V oklepaju je nato dodan pomenski opis v slovenščini, ki nam popolnoma približa izraz smuči v današnjem pomenu. Po Pleteršniku so to »dolge tenke deske, pod podplate privezane v hojo po snegu«. Kot vir je na prvem mestu navedeno slovarsko gradivo Frana Miklošiča, sledi mu Caf. Poleg sta navedeni tudi dve širši območji, Dolenjska (Dol.) in Notranjska (Notr.) z virom Iz popotne torbe Frana Erjavca. Druge pomenske razčlembe v okviru te iztočnice za obravnavano tematiko niso pomembne.

Naslednji izraz s korenom smuč, naveden v Pleteršniku, je glagol smúčati smučim. Njegova paradigmatika se ne pokriva z izrazom, ki se nanaša na sneg (smučati smučam), zato ju lahko obravnavamo kot homonimna izraza. Glagol smučkati in samostalnik smuče pomensko prav tako nista vezana na sneg. Vendar oba izraza vsebujeta pomensko sestavino hitenja, ki je bila podlaga, da so se izrazi lahko začeli pomensko širiti tudi na področje nove športne dejavnosti. Taki pomenski prenosi niso bili potrebni pri samostalnikih smučice in smučke. Smučice so sopomenka izrazu smučke; ta izraz pa je prikazan kot manjšalnica od smuči.

S stališča smučarstva sta zanimiva drugi in tretji pomen pri izrazu smuka, pri katerem je v drugem pomenu naveden isti nemški ustreznik (die Schlittenkufe - slovensko sanica) kot pri izrazu smuč, v tretjem pa le delno drugačen (eine Art Schneeschuhe pri izrazu smuč : der Schneeschuh pri izrazu smuke). Zveza s pomenom hoja oziroma drsenje po snegu je tako razpoznavna.

\footnotetext{
${ }^{16}$ Femininum plurale.

${ }^{17}$ Fran Erjavec, Iz potne torbe. V: Letopis Matice slovenske za leto 1882-1883. Ljubljana, $1883,238$.
} 
V Pleteršnikovem slovarju je opazna navedba virov z Dolenjske in Notranjske. Nedvomno je v to območje mogoče zajeti Levstikovo domače okolje in Bloško planoto, kar je dodaten vir, pridobljen po drugi poti, za obstoj izraza smuči v pomenu priprava iz dveh desk v tem prostoru. Navedba Dolenjske in Notranjske je dokaz, da je tudi Pleteršnik izraz smuči in smuke registriral v narečni rabi. Izraz smuč v današnjem pomenu je bil torej prvotno narečni izraz na delu Dolenjske (»okrog Loža, Oblok in Lašč «) in na Notranjskem (Bloke). $\mathrm{V}$ tem slovarju sta izmed šestih izrazov torej dva, ki imata pomen smuči $\mathrm{v}$ današnjem pomenu (smuč(i) in smuke). Ker se delno pokrivajo tudi viri zanju (Cigale), lahko predvidevamo, da sta živela na istem območju. ${ }^{18}$

Pozornost vzbuja tudi Pleteršnikova navedba izrazov, ki so del današnje smučarske terminologije (smučati, smuče, smučke; smučkati), a so v Pleteršnikovem slovarju prikazani v pomenih, ki so se opustili ali pa so mogoče danes $\mathrm{v}$ rabi še kje v narečjih. Ne glede na to, je navedba teh izrazov, čeprav v delno drugačnem pomenu, sama po sebi zadosten dokaz, da so izrazi bili del takratnega leksikalnega sistema in tako pogosti, da so bili zajeti v slovar. S pomenskimi sestavinami (hitenje, drsenje), ki so bistvene tudi za današnje pomene teh izrazov, je bila dana podlaga za pomenski razvoj v smučarske termine. Trditev, da jezik rabi manjšo moč za razvijanje pomena kot pa za zapolnjevanje belih lis z oblikovanjem popolnoma novega izraza, je omenjena le kot predpostavka. Kljub temu pa sloni na dejstvu, da je pri stopenjskem razponu od že oblikovanega izraza, čeprav z drugačnim pomenom, do uveljavitve novega pomena le krajša pot, kot pa če izraz na novo nastaja. Prva stopnja je namreč že izpolnjena.

Smuška terminologija Rudolfa Badjure (1921) je dala izrazu smuči in tej besedni družini vidno mesto. Ob tej prvi slovenski zbirki smučarskega izrazja je smiselno navesti glavni cilj, ki si ga je zadal avtor. Ta je »pojasniti novincu smučarju turistu najpoglavitnejše pojme in izraze, ki jih rabi pri smuškem športu, da se mu ni treba posluževati tujih, grdih spakedrank«. Iz citata je mogoče

${ }^{18}$ Zagonetno je ugotavljati, kako je potekal razvoj od pomena smuči > sanke do današnje stopnje smuči > priprava iz dveh desk. Raba izraza smuči v pomenu (večje) sanke je bila v narečjih živa še v 60. letih 20. stoletja. Avtorica sestavka se spominja, da so v Žireh še v 60. letih 20. stoletja današnje smuči imenovali ški, (večje) sanke pa smuči (smàči). Popularizacija območja, kjer se je rabil izraz smuči v pomenu naprava za drsenje po snegu, to pa je območja Dolenjske in Notranjske (Bloke) v strokovnih časopisih, je zagotovo prispevala svoje, prav tako Badjurovo priporočanje teh smučarskih izrazov iz njegove Smučarske terminologije in registracija v Slovenskih pravopisih, kot bo navedeno v nadaljevanju. K temu lahko dodamo še Badjurovo organiziranje smučarskih tečajev. Prav jezikovni položaj poučevanja je ugoden za širjenje določene terminologije. Seveda so to le domneve, ki pa ne zajamejo nepredvidljivih psiholingvističnih motivov. - Tudi zelo stari zapisi skandinavskega, ruskega, laponskega izrazja omenjajo izraz sani, ki bi bile lahko tudi ime za smuči, kar je razbrati iz podob, na katerih je mogoče natančno videti smučarje in smuči. Podobno velja za izraze krplje in smuči, kjer se le s slike vidi, za kaj gre. Torej tudi v domovini prvobitnega smučanja prvotno niso ločevali smuči od sani. Tudi stari nemški Schneeschuh je prvotno pomenilo krplje in tudi smučka, kar je mogoče razbrati s slik. (Pojasnilo Aleša Gučka.) 
razbrati dvojnost tedanje smučarske terminologije, na eni strani domača, na drugi pa tuje, po izvoru nemško izrazje, z današnjega socialnozvrstnega stališča nižje pogovorno, do katerega ima avtor odklonilen odnos. ${ }^{19}$

Prva od Badjurovih ugotovitev v Smuški terminologiji je, da so »sredstva in priprave, ki jih denemo na noge, da se nam ne vdira toliko, kadar hodimo po snegu, /so/ dvojne vrste: krplje in smuči.« V nadaljevanju opisuje krplje, nato pa se osredotoči na smuči:

$V$ debelem, mehkem snegu pa s krpljami ne prideš daleč. V tem slučaju rabimo tanke, dolge deske pod nogami, ki imajo pred krpljami i to neprecenljivo vrednost, da z njimi tudi lahko drsaš; imenujemo pa le-te priprave:

2. smuči, pl.f. od smuč, i. (Bl)

3. smúke, pl.f. od smuka, e. (Bl)

4. smúče, pl.f. od smuča, e. (Bl)

5. smučice, pl.f. od smučica, e; $t$. s.: otroške smučke,

6. smučke, pl.f. od smučka, e, deminutiv od smuči, s. manjše, lažje vrste. (Bl) (Badjura 1921: 3)

Badjura loči celo posamezne vrste smuči. Tako pravi:

Razločujemo pa: smuči in smúčke za navadno rabo, smuke ali smuče (težja in daljša vrsta smuči), ki jih rabijo smučarji skakači posebno za skok in pa male smučke za deco, ki jih nazivljemo smučice (Badjura 1924: 21).

Natančnost se izraža v njegovem priporočenem izgovoru ob izrazih smuči in smučice; po njegovem naj bi se glas /u/ izgovarjal kot »polglasni e«. Ob opozorilu na ta izgovor in ob upoštevanju pojava slekanja ${ }^{20} \mathrm{v}$ nekaterih slovenskih narečjih se nam tudi izraz šmeče iz 19. stol. razkrije v novi, bolj nazorni luči. Badjura glede na širino smuči opredeljuje še izraze šestice, sedmice, osmice, devetice, lovske ali letne smučke (Badjura 1924: 22).

Smučarsko izrazje, zbrano pri Badjuri, je odraz velike razširjenosti predmeta pričujoče obravnave - smuči. To razkriva tudi Badjurova pripomba ob navedbi manjšalnice smučice: »Na Blokah ima že vsak petletni fantiček ali punčka svoje smučke.« (Badjura 1921: 3) Posameznim vrstam glede na namen se pridružujejo izrazi s številskim korenom (šestice, sedmice idr.). Ti so se opustili, a dokazujejo tudi tehnološko pestrost desk za smuči. Batagelj zapis domačih izrazov povezuje z načrtnim prizadevanjem za uveljavitev »čistih«, z narodnim uzaveščanjem povezanih slovenskih izrazov (Batagelj 2008: 52-58). Nedvomno je to neizpodbitno zunajjezikovno dejstvo, ki ga socioligvistika ne

${ }^{19} \mathrm{~V}$ nadaljevanju Badjura v več razdelkih obravnava izrazje, ob katerih so zapisani tudi »tuji, grdi«: ob dereznikih Badjura na primer opozarja, naj se ne rabi gurte, ob nahrbtniku ne rukzak itd. Razdelek z naslovom Smuška tehnika začne z naročilom, v katerem je zapisan tudi izraz ski: »Gibanje po snegu na smučeh izražamo jako različno - samo ne 'ski voziti'," (poudaril Rudolf Badjura). Torej je vzporedno ob izrazu smuči živel tudi izraz ski.

${ }^{20}$ SSKJ: slekati /.../ lingv. izgovarjati sičnike in šumevce tako, da ni razlike med s in š, z in ž: v nekaterih vaseh v Baški grapi slekajo. 
zanemarja, dodati pa je mogoče tudi normo jezikovnih priročnikov, ki smuči že od Pleteršnika deklarirajo kot edini termin za to napravo. Levčev Slovenski pravopis iz leta 1999 nima še nobenega izraza, ki bi se navezoval na smučarstvo. Prav nenavadno dejstvo pa je, da ima Breznikov Slovenski pravopis iz leta 1920 kljub zelo skromnemu slovarskemu delu že registriran izraz smuč, ž, Breznik-Ramovšev pravopis iz leta 1935 pa prinaša celo besedno družino: smuč -i ž; nav. množ. smuči /.../; smučke, smučati se, smučar, smučarka, smučkati se, smuka. Ob dejstvu, da izraza sneg ni, je to v smučarski terminologiji prava mala revolucija.

S priporočenimi izrazi za smuči v Badjurovi Smuški terminologiji in z upoštevanjem izrazov v normativnih jezikovnih priročnikih so bili dani temelji za njihovo nadaljnjo uveljavitev. Med obema vojnama se je z razvojem smučarstva ta izraz tako dokončno utrdil v knjižnem jeziku. Joža Glonar ima v Slovarju slovenskega jezika (Glonar 1936: 359) besedno družino že popolnoma »posodobljeno«: smučar; smučati, smučim švigati; smučati, smučam se: na smučeh; - smučkati se; smuči /.../; smučice: majhne smuči za otroke; smučina; smučka: posamezna smuč; smučke - smuči; smuka 1. sneg ali teren, ugoden za smučanje; tam je dobra smuka; za jutri se obeta dobra smuka; /.../

Izrazje samo pa posredno odraža tudi premik v vrednotenju novega športa. Že leta 1931 se je začelo smučanje obravnavati kot slovenski nacionalni šport. ${ }^{21}$ Obenem se pojavlja tudi ponos, da Slovenci nismo prevzeli izraza ski z nemško govorečega območja, kar je sicer pogosto pri drugih evropskih narodih. Batagelj navaja eno od tovrstnih mnenj iz takratnega časopisja: ${ }^{22}$

Že mladim je treba privzgojiti ponos, da smo Slovenci v vsej Srednji Evropi edini, $k i$ poznamo že stoletja smuči in imamo poleg Rusov in Norvežanov edini svoj lastni izraz ${ }^{23}$ za smučke (Batagelj 2008: 47).

Širjenje pomenskega polja se je zato $\mathrm{v}$ naslednjih desetletjih opravljalo $\mathrm{z}$ dodajanjem vrstnih pridevnikov k jedrnemu samostalniku: túrne smučí, álpske smučí, tekáške smučí. To se dogaja še danes. Ob pojavu novih karving smuči se je pojavila množica slovenskih sopomenk. Dejanje samo je zajeto v izrazu zarézne smučí, geometrija smuči v izrazu ukrívljene smučí, smučí s poudárjenim

${ }^{21} \gg \mathrm{K}$ današnji mednarodni zimski olimpijadi v Bohinju. Smučanje - slovenski narodni šport. Samo v skandinavskih deželah je smučanje tako staro kot na Slovenskem, sicer pa nikjer v Evropi. Ima namreč 700-letno tradicijo in že Valvasor nam pripoveduje o smučanju bloških kmetov. V zadnjih letih se je pa z neverjetno naglico razširilo po vsej Sloveniji in danes smučata kmet in meščan, moški in ženska, staro in mlado.« Ilustrirani Slovenec, tedenska priloga Slovenca, leto VII, 1. februar 1931, št. 5, str. 35.

${ }^{22}$ Vrtec, let. 71 (1940-41), št. 6, str. 223.

${ }^{23}$ To se pojavlja v literaturi o smučanju tudi dandanašnji. Prim. Aleš Guček, Po smučinah od pradavnine, Ljubljana 1998, str. 8: »Posebej smo lahko ponosni, ker smo med redkimi narodi na svetu, ki ima svoje posebno ime za 'smuči' namesto po Skandinavcih prevzete besede 'ski'." 
stránskim lókom; v ta okvir bi sodil tudi izraz oblikováne smučí. Metaforični poimenovanji sta metúljaste smuči in lopátaste smučr ${ }^{24}$

Tehnološki razvoj se v jeziku ni odrazil samo v novih izrazih, ampak tudi v poimenovalni potrebi po opredelitvi »prejšnjih« smuči. Izraz smuč brez poudárjenega stránskega lóka je zanikani izraz novega poimenovanja, a kljub temu precizno opredeli pretekle smuči. Pridevnik klasičen v zelo pogostem izrazu klásične smuči pokriva široke kolokacijske možnosti, kar ne pripomore k enoznačnosti pomena. Ob tem se pojavlja še izraz rávne smučí, katerega pomenska podlaga zadeva geometrijo smuči, kar je za natančnost pomena bistveno. V pogovornem jeziku se sliši tudi izraz súlice. Izraza paralélne smučí, ki se tudi pojavlja, stroka ne priznava, ker naj bi bila ta zveza pogovorna za pomen paralelno postavljene smuči.

\section{Sklep}

Glede na prikaze izraza smuči v Pleteršniku in posamezne zapise iz 19. stoletja je bil ta izraz prvotno narečen. Iz časa, ko so smuči bile lesene, se je ohranil izraz díle, dílce, dèske, dèščice, ki se danes rabijo kot pogovorni izrazi za sodobne smuči. Glede na les, iz katerega so izdelane, sta motivirana izraza híkorice (smuči iz hikorijevega lesa ${ }^{25}$ ), jesénove smučí. Pridevniške zveze opredeljujejo tudi drugačno snov, iz katere so smuči izdelane (plástične smuči), izvor (ljúdske smučí blóške smuči (Bloke), nováške smuč (Novaki), póhorske smuči (Pohorje)). Teren zaznamujejo izrazi álpske smuči, túrne smučí, namen uporabe izrazi skakálne, tekáške (v preteklosti lôvske smučí, lógarske smuči). Obliko oz. geometrijo smuči opisujejo izrazi smuči s poudárjenim stránskim lókom (prevzeto kárving), rávne smučí, klásične smučí. Pomenska sestavina razsežnosti tiči v izrazu krátke smučí, kar je podomačeni izraz za prevzeti big foot. Način izdelave opredeljuje izraz lépljene smuči (v preteklosti žebljáne smuči).

V žargonu se pojavljajo še izrazi, ki so besedotvorno motivirani s stvarnim lastnim imenom. To je ime izdelovalca, tovarne: Elan > elánke. Angleško govorno postavo (racing) oziroma krajšavo (RC) ima izraz ercêjke > smuči z oznako RC. Ob pojavu smučanja po starem se pojavljajo izrazi, povezani z njim, kot so lók smúčka, lók smučí, redko tudi smúčka z ográjo. Opirajo se na novaško smučanje s posebno smučko, ki se je pojavilo po prvi svetovni vojni v zaselku Novaki pri Cerknem.

Izrazi za sneg in smuči se pojavljajo v vseh socialnih jezikovnih zvrsteh; obe pojmovni skupini sta tvorni še danes. Pomemben delež izrazov iz obeh skupin je v preteklosti živel v narečjih. Od tu so prešli v knjižni jezik in so

${ }^{24} \mathrm{Za}$ uveljavitev domačih izrazov se je s številnimi članki po strokovnem in siceršnjem časopisju posebej prizadeval Aleš Guček.

${ }^{25}$ Slovar slovenskega knjižnega jezika: híkori -ja m (i) severnoameriško drevo, ki daje trd, prožen les. 
sedaj nepogrešljive enote slovenske smučarske terminologije. Živost le-te se izkazuje tudi v izraznem odzivanju na nove tehnološke dosežke. ${ }^{26}$

\section{LITERATURA}

Rudolf BADJURA, 1921: Smuška terminologija. Ponatis po Sportu 1920/1. Ljubljana.

- -, 1924: Smučar. Ljubljana.

Borut BATAGELJ, 2008: Socialna zgodovina smučanja na Slovenskem. Doktorska disertacija. Ljubljana. Filozofska fakulteta Univerze v Ljubljani. Oddelek za zgodovino.

Francka BENEDIK, 1990: Poimenovanje gozda in refleksi e v besedi sneg v slovenskih govorih. Razprave XIII. Slovenska akademija znanosti in umetnosti. Ljubljana. Razred za filološke in literarne vede.

France BEZLAJ, 1995: Etimološki slovar slovenskega jezika, Tretja knjiga, P-S, Ljubljana.

Borut ČRNIVEC in Andrej TERČELJ, 1997: Skrivnosti nedotaknjenih strmin. 101 nasvet za smučanje zunaj urejenih smučišč. Samozaložba. Ljubljana.

Arnoll DALEN, 1998: Scandinavian ski terminology. History of Skiing. Conference Holmenkollen. Oslo 16.-18. 9. 1998. 50-57.

Ilustrirani Slovenec, tedenska priloga Slovenca. Leto VII, 1. februar 1931, št. 5.

Joža GLONAR, 1936: Slovar slovenskega jezika. Umetniška propaganda. V Ljubljani.

Aleš GUČEK, 1998: Po smučinah od pradavnine. Ljubljana: Magnolija.

Drago KLADNIK et al., 2005: Geografski terminološki slovar, ZRC SAZU. Geografski inštitut Antona Melika. Oddelek za geografijo Filozofske fakultete Univerze v Ljubljani. ZRC SAZU. Inštitut za slovenski jezik Frana Ramovša. Ljubljana: Založba ZRC, ZRC SAZU.

Fran LEVEC, 1899: Slovenski pravopis.

Boris OREL, 1964: Bloške smuči. Vprašanje njihovega nastanka in razvoja. Ljubljana. Slovenska akademija znanosti in umetnosti. Inštitut za slovensko narodopisje.

Zdravko PETKOVŠEK in Zvonka LEDER (ur.), 1990: Meteorološki terminološki slovar. Slovenska akademija znanosti in umetnosti in Društvo meteorologov Slovenije. Ljubljana.

${ }^{26}$ Za pomoč pri iskanju literature in za številne strokovne dopolnitve se najlepše zahvaljujem Alešu Gučku, avtorju več knjig o smučarstvu, zlasti o njegovi zgodovini, in pobudniku Slovenskega smučarskega slovarja, za strokovno presojo pa prav tako turnemu in alpinističnemu smučarju mag. Andreju Terčelju. 
Planinski terminološki slovar, 2002. Slovensko-angleško-nemško-francosko-italijanski slovar planinskega, alpinističnega, plezalskega izrazja. Komisija za izdelavo Planinskega terminološkega slovarja. Ljubljana: Založba ZRC, ZRC SAZU.

Maks PLETERŠNIK, 1974: Slovensko nemški slovar, A-O, P-Ž, reproducirani ponatis. Ljubljana: Cankarjeva založba.

Slovar slovenskega knjižnega jezika, 1994. Slovenska akademija znanosti in umetnosti. Znanstvenoraziskovalni center Slovenske akademije znanosti in umetnosti. Inštitut za slovenski jezik. DZS.

Marko SNOJ, 1997: Slovenski etimološki slovar. Ljubljana: Mladinska knjiga.

Pavle ŠEGULA, 1986: Sneg, led, plazovi. Priročnik za planince, smučarje in druge. Ljubljana. Planinska zveza Slovenije.

- - (ur.), 1995: Večjezični slovar - Sneg in plazovi. Gorska reševalna služba pri Planinski zvezi Slovenije. Ljubljana.

Jože TOPORIŠIČ, 2000: Slovenska slovnica. Založba Obzorja.

Janez Vajkard VALVASOR, 1994: Slava vojvodine Kranjske. Mladinska knjiga.

\section{THE TERMS FOR SNOW AND SKIS IN SLOVENIAN SKIING TERMINOLOGY}

Slovenian skiing has a long tradition. Skiing at Bloke was described by J. V. Valvasor (1689). In line with the conceptual needs arising from a specific movement with a certain device, which was based on daily practical needs, an expression probably existed for it. The origins of Slovenian skiing terminology date back to the 19th century. Particularly in the second half of the century, various newspapers already published dialect entries of the term "skis" from different parts of Slovenia in its present-day meaning, which proves that "skis" was initially a dialect term. This is confirmed by the entries of terms from the word family containing the root word skis in Pleteršnik's dictionary. Skiing terminology was one of the first to be written. Its foundations were laid in the works of Rudolf Badjura, Smuška terminologija (Skiing Terminology) (1921) and Smučar (Skier) (1924). Badjura's list of skiing terms is not based solely on the currently recognised method of proceeding from materials and word use, which is decisive for their registration in collections; he also documented the sources (Bloke in the Notranjska region and individual places in Gorenjska). Among the terms registered in his works are many expressions for snow and skis. These are distinguished by their purpose of use and scope. The term ski(s) was registered in Slovenski pravopis (Slovenian Orthography) in 1920, and later extended into a word family in the orthography issued in 1935 and subsequent years. In the Dictionary of the Slovenian Language (1936), Joža Glonar listed the entire word family using completely modern meanings. In the following decades, its semantic field expanded with the addition of relational adjectives to the head noun: race skis, piste skis, allmountain skis, powder skis, freeski skis, backcountry skis. This is still occurring today. With the appearance of new carving skis, a multitude of Slovenian synonyms appeared (skis with accentuated side arcs, groove skis, butterfly skis, and others). This reveals the creativity of Slovenian skiing terminology in the present-day, which is amply evident in modern publications (Pavle Šegula, Sneg, led, plazovi (Snow, Ice, Avalanches) 
(1986), and his multilingual dictionary - Sneg in plazovi (Snow and Avalanches) (1995), Borut Batagelj, Socialna zgodovina smučanja na Slovenskem (Social History of Skiing in Slovenia) and Slovenski smučarski slovar (Slovenian Skiing Dictionary), which is prepared in Scientific Research Centre of the Slovenian Academy of Sciences and Arts. 